\title{
Arthroderma persicolor
}

National Cancer Institute

\section{Source}

National Cancer Institute. Arthroderma persicolor. NCI Thesaurus. Code C127686.

A species of dermatophyte fungi in the genus Arthroderma. 